\title{
Knowledge, Attitude, and Behavior of Egyptian Medical Students Toward the Novel Coronavirus Disease-19: A Cross-Sectional Study
}

\author{
Shaimaa A.M. Abd El Fatah ${ }^{1 *}$, Marwa Rashad Salem ${ }^{1}$, Ahmed Sallam Abdel Hakim², Eman D. El Desouky ${ }^{3}$ \\ ${ }^{1}$ Department of Public Health and Community Medicine, Faculty of Medicine, Cairo University, Cairo, Egypt; ${ }^{2}$ Faculty of \\ Medicine, South Valley University, Quena, Egypt; ${ }^{3}$ Department of Epidemiology and Biostatistics, Faculty of Medicine, National \\ Cancer Institute, Cairo University, Cairo, Egypt
}

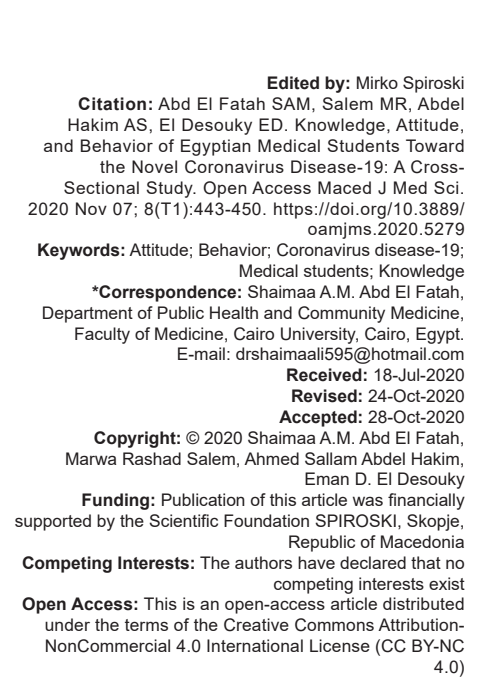

\section{Abstract}

BACKGROUND: People in times of pandemics, crave after any medical field member (including medical students) to gain their knowledge and correct their behaviors.

AIM: We aimed to assess medical students' coronavirus disease (COVID)-19 related knowledge, attitude, and behavior (KAB).

METHODS: The study is an exploratory cross-sectional study, conducted among medical students using an online survey. Medical students were classified according to their current academic year into either early year's group (firs 3 years in the medical school) or final year's group (past 3 years in the medical school).

RESULTS: A total of 2255 students completed the questionnaire. Regarding their COVID-19 related knowledge; $63.4 \%$ gave unsatisfactory responses (answered $<75 \%$ of the questionnaire items correctly). Most of males $(62.9 \%)$ and females $(64.1 \%)$ gave unsatisfactory responses.

CONCLUSION: Most of students had unsatisfactory responses of the current pandemic; however, the final year's group had a significantly higher score in nearly all questionnaire (KAB) subsections than the early year's group. The majority of both groups significantly believed that there are undeclared numbers in Egypt. Facebook and other platforms were the most common sources of information.

\section{Introduction}

Coronavirus (CoV) disease (COVID-19), the new comer to the viral, droplet infectious disease family has aroused attention of millions of researchers and physicians all over the world [1].

Worldwide, since pneumonia of unknown cause detected in Wuhan, China; and up till now (Mid May 2020); 216 territories or countries have reported cases. The total confirmed cases are 4,248,389; the total recovered cases are $1,521,397$, and finally the total deaths are 292,046 [2], [3].

Egypt, with more than 105 million citizens, is the most populous country in North Africa, Arab region, and the Middle East. This big number of citizens could be correlated with a grave, drastic risk of spread, and mortality [4]. In Egypt, the official figures brought out by Egyptian Ministry Of Health and Population (MOHP) exhibit that the total infected cases are 10,431, the total recovered cases are 2172 , and finally the total deaths are 556 [5].
The epidemiological profile of COVID-19 is currently under vigorous investigations; starting from causative organism origin, prevention (General and specific), treatment, and finally control measures [6]. The WHO carefully monitors this emerging pandemic and information is updated continuously as more evidence becomes available [7].

Medical students are the future healthcare workers (HCWs) and the volunteers in times of need. Addressing their current knowledge, attitude, and behavior (KAB) of this newly emerging pandemic is a vital necessity, not only to be able to protect themselves but also to disseminate the correct information to their local communities [8]. People in times of pandemics, and sever fright crave after any medical field member (including medical students) to gain their knowledge and correct their behaviors [9], [10].

Infection Prevention and Control (IPC) recommendations can only be set after recognizing how HCW and in the heart medical students, perceive COVID19 virus and translate their knowledge into practical 
guidelines to minimize risk of infection [11], [12]. That is why we urged to perform this survey among medical students to assess their COVID-19 related KAB.

\section{Methods}

\section{Study design and setting}

The study is an exploratory cross-sectional study, performed among medical students to assess their COVID-19 related KAB. An online survey through Google Form was created, and disseminated through the Facebook application, one of the most frequently utilized social media in Egypt. To attain a high response rate, groups with large numbers of medical students were approached by the researchers. To obtain permission to spread this survey, requests were sent to administrators of these groups. Then, the link of the survey with an encouraging statement including its purpose was posted by the researchers.

\section{Sample size and sampling technique}

A total of 2255 medical students were recruited by consecutive sampling technique during the study duration from March 1, 2020, to April 1, 2020. Participants were excluded from the study if they were not medical students.

\section{Data collection tool}

A pre-tested electronic questionnaire was used to collect data from the study participants. It included four sections:

\section{Socio-demographic characteristics}

Age, sex, education, university, and educational year.

Medical students involved in this study were classified according to their current academic year into either the early year's group (first 3 years in the medical school) or final years group (last 3 years in the medical school).

\section{COVID-19}

Knowledge of study participants regarding

Composed of a total of 30 items addressed modes of transmission, the symptoms, and complications (12 questions), and prevention and treatment (18 questions). The questions formatted in close-ended with yes, no, and do not know options. The questions were coded so that true answers were given a score of 1 , while wrong answers or answering with I don't know were given a score of 0 . The total raw score (if all answers are correct) was 30 . Percent score was calculated by dividing the raw score over 30 (maximum achievable score) and then multiplying the result by 100 .

\section{Knowledge status was classified into satisfactory and unsatisfactory}

Satisfactory knowledge: considered when the students gave correct answers to $75 \%$ or more of the questionnaire items.

Questions used in this section were adopted from the available literature [13], [14].

For further assessment of study participants' attitude toward COVID- 19; six questions were used to assess medical student's attitude toward COVID-19. The questions formatted in close-ended with yes, no, and do not know options. Questions used in this section were adopted from the available literature [13], [14].

\section{Attitude questions included inquiry on}

Possibility to prevent infection by following the methods of prevention declared by the MOHP, undeclared numbers in Egypt, readiness to take corona vaccination if present, ability of government in Egypt to control the spread of the disease, if this virus is a biological warfare.

Five questions were used to assess behavior formatted in close-ended with yes, no. Questions used in this section were adopted from the available literature [13], [14].

\section{Behavior questions included inquiry on}

Worries that someone in family will be ill, wearing gloves, wearing masks in daily activities, using alcohol or sterile gel to cleanse hands constantly, washing hands many times a day, using diluted chlorine with water to cleanse the surfaces.

Sources of knowledge about COVID-19; using multiple options format, which included scientific websites, literature, colleagues and or health-care providers, television, internet, Facebook, WhatsApp, WHO website, CDC, MOHP, and others including Twitter, and Instagram.

A pilot test was performed to test the clarity of the questions by interviewing ten participants (not included in the study). The required modifications were applied. The content of the questionnaire was validated by four faculty members who are experts in public health and the required modifications were done. Reliability was tested using internal consistency and a Cronbach's Alpha ranging from 0.59 to 0.80 was found for the 30 knowledge questions. 


\section{Statistical analysis}

Statistical Package for the Social Science program (SPSS, version 24) was applied for data analysis. The median and interquartile range were utilized to sum up quantitative variables while frequency and percentage were utilized, to sum up qualitative variables. Chi-square test and cross-tabulations were done for bivariate analysis. Meanwhile, Mann-Whitney test was used for quantitative data analysis. $p<0.05$ was considered statistically significant.

\section{Ethical considerations}

Study approval was acquired from the Research Ethics Committee, Faculty of Medicine, Cairo University under number F-15-2020.

Informed consent was attained directly from the study participants after clarification of the study aim and importance of the online-form before data collection. Only those who agreed were included and those who refused were excluded from the study by submitting empty form after answering "Not willing to participate." All procedures for data collection were treated with confidentiality according to the Helsinki Declarations of biomedical ethics.

\section{Results}

A total of 2255 students completed the questionnaire; about half of them were males (44.9\%). About two-thirds of the students $(66.7 \%)$ belonged to the early year's group. Regarding their response to the questionnaire item; $63.4 \%$ gave unsatisfactory knowledge responses. Most of males (62.9\%) and females $(64.1 \%)$ gave unsatisfactory responses $(p=0.564)$. Similarly, most of the early years group $(67.1 \%)$ and the final years group $(56.6 \%)$ significantly gave unsatisfactory responses $(p<0.001)$ (Figure 1).

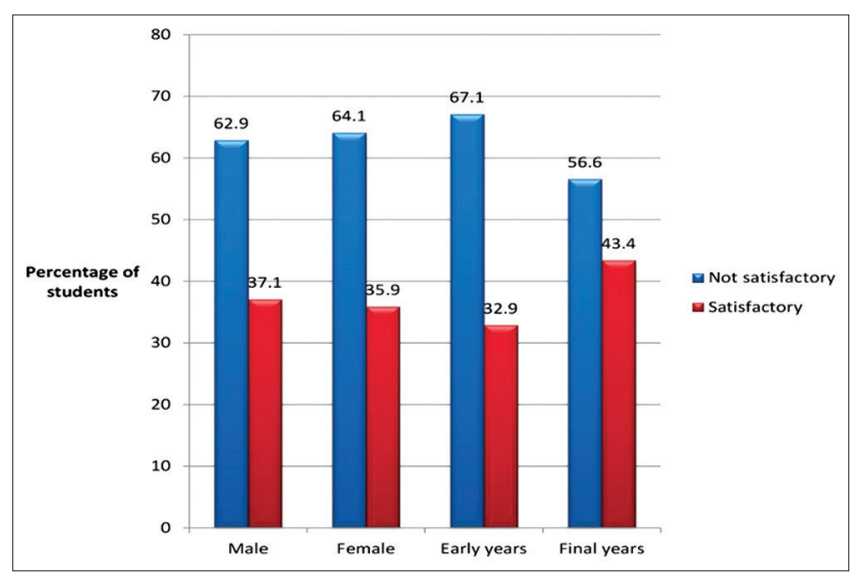

Figure 1: Summarization of the level of knowledge about coronavirus disease-19 among medical students, Egypt
Figure 2 shows that the Facebook was most common source of medical students' information about COVID-19 virus regardless of their academic year, whereas TV (57.4\%) and WhatsApp groups (18.7\%) were significantly the major sources of information for early years group, the doctors (or colleagues) (54.7\%), and the WHO $(16.8 \%)$ were the major sources of information for final years group $(p<0.001)$.

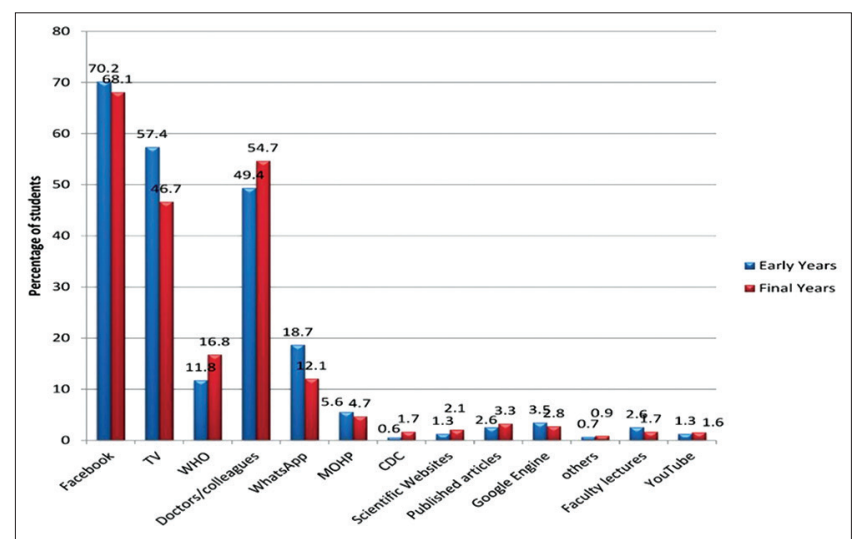

Figure 2: Source of information about coronavirus disease-19 among medical students, Egypt

Concerning students' knowledge about COVID19 transmission, symptoms, and testing; most of the final years group significantly and correctly responded to most of the questionnaire items; $p<0.001$. Whereas most of the early years group responded significantly and correctly to only three questions as follows: Direct contact without protection with infected wild animals $(60.1 \%)$, the possibility of infecting young people are less than the elderly (55.2\%) and COVID-19 testing is done for returnees from traveling from countries with societal prevalence even without the appearance of symptoms $(86.5 \%) ; p<0.001$. The difference in the median of the total knowledge score across the 12 items of this questionnaire section between the early and final year's groups was not significant (Table 1).

As for students' knowledge about COVID-19 prevention and treatment; most of the final year's group correctly responded to almost all questionnaire items except for only five questions where the early year's group surpassed them. The five questions were about: Eating more nutritious foods to strengthen the immune system $(96.8 \%)$, covering nose and mouth during coughing $(99.1 \%)$, abstinence from touching sick animal (79.6\%), good cooking of meat and heating milk to avoid transmission of the disease $(79.2 \%)$, and possibility to treat COVID-19 with regular cold medication in cases without complications (36.5\%). The difference in the median of the total knowledge score across the 18 items of this questionnaire section between the early and final years groups was statistically significant; $p<0.001$ (Table 2).

The attitude assessment section of the survey disclosed that the majority of both the final year's group $(84.8 \%)$ and the early year's group $(78.2 \%)$ believed that there are undeclared numbers in Egypt with a statically 
Table 1: Comparison between early and final years medical students regarding COVID-19 related knowledge (Disease transmission, symptoms, and testing)

\begin{tabular}{|c|c|c|c|c|}
\hline Disease transmission, symptoms, testing & Correct answer & $\begin{array}{l}\text { Early years } \\
(\mathrm{n}=1503) \text { No. }(\%)\end{array}$ & $\begin{array}{l}\text { Final years } \\
(\mathrm{n}=752) \text { No. }(\%)\end{array}$ & $p$-value* \\
\hline Direct contact without protection with infected wild animals & Yes & $903(60.1)$ & $343(45.6)$ & $<0.001^{*}$ \\
\hline The virus is transmitted between humans by droplets (sneezing) & Yes & $1447(96.3)$ & $740(98.4)$ & $0.005^{*}$ \\
\hline The incubation period is from 2 to 14 days & Yes & 1405 (93.5) & $730(97.1)$ & $<0.001^{*}$ \\
\hline Fever, coughing, and shortness of breath are symptoms of infection with the new coronavirus & Yes & $1483(98.7)$ & $748(99.5)$ & 0.081 \\
\hline COVID-19 symptoms could be self-limited? & Yes & 1054 (70.1) & $631(83.9)$ & $<0.001^{*}$ \\
\hline Complications of the disease are more severe in the elderly and people with chronic diseases such as diabetes & Yes & 1471 (97.9) & $745(99.1)$ & $0.040^{*}$ \\
\hline The possibility of infecting young people is less than elderly & Yes & $829(55.2)$ & $357(47.5)$ & $0.001^{*}$ \\
\hline Is it possible for the patient to be infected without any symptoms? & Yes & $1258(83.7)$ & $693(92.2)$ & $<0.001^{*}$ \\
\hline COVID-19 testing is done for contacts of positive cases without the appearance of symptoms? & No & $273(18.2)$ & $169(22.5)$ & $0.015^{*}$ \\
\hline COVID-19 testing is done for contacts of positive cases when symptoms appear during active surveillance? & Yes & $1035(68.9)$ & $543(72.2)$ & 0.102 \\
\hline $\begin{array}{l}\text { COVID-19 testing is done for returnees from traveling from countries with societal prevalence even without } \\
\text { the appearance of symptoms }\end{array}$ & Yes & $1300(86.5)$ & 575 (76.5) & $<0.001^{*}$ \\
\hline $\begin{array}{l}\text { COVID-19 testing is done for suspected cases, provided symptoms occur } \\
\text { Total score }\end{array}$ & Yes & $805(53.6)$ & $439(58.4)$ & $0.030^{*}$ \\
\hline Median (IQR) & & $9(8-10)$ & $9(8-10)$ & 0.288 \\
\hline
\end{tabular}

p $<0.05$ COVID: Coronavirus disease.

(Disease prevention

Table 2: Compari
and treatment)

\begin{tabular}{|c|c|c|c|c|}
\hline Disease prevention and treatment & Correct answer & $\begin{array}{l}\text { Early year's }(n=1503) \\
\text { No. }(\%)\end{array}$ & $\begin{array}{l}\text { Final year's }(n=752) \\
\text { No. }(\%)\end{array}$ & p-value \\
\hline One of the methods to prevent spread is good ventilation living places & Yes & $1230(81.8)$ & $662(88.0)$ & $<0.001 \dagger$ \\
\hline Staying away from crowded places and keep safe distances & Yes & 1497 (99.6) & $750(99.7)$ & 0.616 \\
\hline Eating more nutritious foods to strengthen the immune system & Yes & $1455(96.8)$ & $713(94.8)$ & $0.021 \dagger$ \\
\hline Washing hands with soap and water helps to prevent transmission of the disease & Yes & $1476(98.2)$ & $746(99.2)$ & 0.063 \\
\hline Covering nose and mouth during coughing & Yes & 1489 (99.1) & $740(98.4)$ & 0.164 \\
\hline Maintaining surfaces clean & Yes & $1492(99.3)$ & 749 (99.6) & 0.345 \\
\hline Abstinence from touching sick animal & Yes & 1196 (79.6) & $486(64.6)$ & $<0.001 \dagger$ \\
\hline Good cooking of intentioned meat and heating milk to avoid transmission of the disease & Yes & $1190(79.2)$ & $478(63.6)$ & $<0.001 \dagger$ \\
\hline There is a vaccination for the new coronavirus & No & $1229(81.8)$ & $682(90.7)$ & $<0.001 \dagger$ \\
\hline COVID-19 can be cured & Yes & $1286(85.6)$ & $679(90.3)$ & $0.002 \dagger$ \\
\hline Antibiotics are the first means to treat disease & No & $1013(67.4)$ & $631(83.9)$ & $<0.001 \dagger$ \\
\hline Is it possible to treat COVID-19 with regular cold medication in cases without complications? & No & $549(36.5)$ & $155(20.6)$ & 0.089 \\
\hline Confirmed cases should go to hospitals regardless the severity of symptoms & No & $642(42.7)$ & $491(65.3)$ & $<0.001 \dagger$ \\
\hline Home isolation must be done for contacts with confirmed cases & Yes & $1233(82.0)$ & $681(90.6)$ & $<0.001 \dagger$ \\
\hline Hospital quarantine must be done for contact with confirmed cases & No & $375(25.0)$ & $349(46.4)$ & $<0.001 \dagger$ \\
\hline Home insolation is done for positive cases & No & $930(61.9)$ & $499(66.4)$ & $0.037 \dagger$ \\
\hline Quarantine must be done for confirmed cases & Yes & $1411(93.9)$ & $716(95.2)$ & 0.197 \\
\hline Hydroxychloroquine is a prophylaxis drug for COVID-19 & No & $436(29.0)$ & $387(51.5)$ & $<0.001 \dagger$ \\
\hline Total score & & & & \\
\hline Median (IQR) & & $14(12-15)$ & $14(13-15)$ & $<0.001 \dagger$ \\
\hline
\end{tabular}

tp < 0.05. COVID: Coronavirus disease.

Table 3: Comparison between early and final year's medical students regarding COVID- 19 related attitude and behavior

\begin{tabular}{|c|c|c|c|}
\hline Attitude and behavior & $\begin{array}{l}\text { Early years }(n=1503) \\
\text { No. }(\%)\end{array}$ & $\begin{array}{l}\text { Final years }(n=752) \\
\text { No. }(\%)\end{array}$ & p-value \\
\hline \multicolumn{4}{|c|}{ Attitude } \\
\hline Yes & $1452(96.6)$ & $737(98.0)$ & \multirow[t]{3}{*}{0.172} \\
\hline No & $26(1.7)$ & $7(0.9)$ & \\
\hline I don't know & $25(1.7)$ & $8(1.1)$ & \\
\hline \multicolumn{4}{|c|}{ If the corona vaccination is present, you will take it or not } \\
\hline Yes & $1350(89.8)$ & $665(88.4)$ & \multirow[t]{3}{*}{0.596} \\
\hline No & $84(5.6)$ & $47(6.3)$ & \\
\hline I don't know & $69(4.6)$ & $40(5.3)$ & \\
\hline \multicolumn{4}{|c|}{ Do you think that there are Undeclared no. in Egypt } \\
\hline Yes & $1176(78.2)$ & $638(84.8)$ & \multirow{2}{*}{$0.001 \ddagger$} \\
\hline No & $131(8.7)$ & $51(6.8)$ & \\
\hline \multicolumn{4}{|c|}{ Can the government in Egypt control the spread of the disease? } \\
\hline I don't know & $196(13.0)$ & $63(8.4)$ & \multirow{4}{*}{$<0.001 \ddagger$} \\
\hline Yes & $610(40.6)$ & $222(29.5)$ & \\
\hline No & $445(29.6)$ & $297(39.5)$ & \\
\hline I don't know & $448(29.8)$ & $233(31.0)$ & \\
\hline \multicolumn{4}{|c|}{ Do you think this virus is a biological warfare? } \\
\hline Yes & $568(37.8)$ & $189(25.1)$ & \multirow[t]{3}{*}{$<0.001 \ddagger$} \\
\hline No & $615(40.9)$ & $376(50.0)$ & \\
\hline I don't know & $320(21.3)$ & $187(24.9)$ & \\
\hline \multicolumn{4}{|l|}{ Behavior } \\
\hline \multicolumn{4}{|c|}{ Are you worried that someone in your family will be ill? } \\
\hline Yes & $1360(90.5)$ & $706(93.9)$ & \multirow[t]{2}{*}{0.006} \\
\hline No & $143(9.5)$ & $46(6.1)$ & \\
\hline \multicolumn{4}{|c|}{ Do you wear gloves in your regular daily activities now? } \\
\hline Yes & $580(38.6)$ & $172(22.9)$ & \multirow[t]{2}{*}{$<0.001 \ddagger$} \\
\hline No & $923(61.4)$ & $580(77.1)$ & \\
\hline \multicolumn{4}{|c|}{ Do you wear masks in your daily activities now? } \\
\hline Yes & $681(45.3)$ & $288(38.3)$ & \multirow[t]{2}{*}{$0.002 \ddagger$} \\
\hline No & $822(54.7)$ & $464(61.7)$ & \\
\hline \multicolumn{4}{|c|}{ Do you use alcohol or sterile gel to cleanse hands constantly? } \\
\hline Yes & $1194(79.4)$ & $621(82.6)$ & \multirow[t]{2}{*}{0.076} \\
\hline No & $309(20.6)$ & $131(17.4)$ & \\
\hline \multicolumn{4}{|c|}{ Do you wash your hands many times a day? } \\
\hline Yes & $1442(95.9)$ & $742(98.7)$ & \multirow[t]{2}{*}{$<0.001 \ddagger$} \\
\hline No & $61(4.1)$ & $10(1.3)$ & \\
\hline \multicolumn{4}{|c|}{ Do you use diluted chlorine with water to cleanse the surfaces? } \\
\hline Yes & $1229(81.8)$ & $628(83.5)$ & \multirow[t]{2}{*}{0.307} \\
\hline No & $274(18.2)$ & $124(16.5)$ & \\
\hline
\end{tabular}


significant difference between early and final year's groups. Most of both groups either completely did not believe or did not know whether the government in Egypt could control the spread of the disease and whether this virus is a biological warfare or not; $p<0.001$ (Table 3 ).

Regarding the behavior section of the survey disclosed the early year's group significantly outreached the final year's in wearing gloves (38.6\%), and wearing masks (45.3\%) in regular daily activities; $p<0.001$. However, the final year's group significantly outreached them in washing their hands many times a day $(p=0.001)($ Table 3$)$.

\section{Discussion}

We assessed the (KAB) of some Egyptian medical students regarding COVID-19. Our study displayed that knowledge and attitude responses toward COVID-19 were not significantly different with regard to socio-demographic variables such as gender and years of experiences. Particularly, gender findings goes in accordance with a recent Egyptian COVID-19 survey among the general public which demonstrated similar and non-significant differences in the knowledge mean scores between male and female participants [15]. Furthermore, our gender findings go in consonance with the disclosures of a previous Malaysian survey among final year medical students which investigated their knowledge of mandatory notifiable infectious diseases (TD) [9]. In developing countries, this is particularly important because the students' future role as HCWs in the country's disease surveillance system is one of the major constituents to fight against TD.

The current study divulged that Facebook and other internet sources were the most widespread sources of students' information. Our findings are in accordance with many national studies which reported that more than seventy percent of participants used the Facebook as the main social media platform in Egypt [15], [16].

More than $75 \%$ of Facebook users in Egypt are in the youth age groups between 18 and 40 years including medical students. In 2019, Facebook platform users increased from 33 million in 2016 to more than 40 million [17].

In the same time, many international studies similarly reported social media and television as the chief information sources [18], [19], [20].

Meanwhile, this differs from the findings of a regional study in Saudi Arabia, where $50 \%$ of the participants relied on the official Ministry of Health website as the principal information source about Middle East respiratory syndrome (MERS) [10]. Taken together, these findings endorse the weightiness of using such platforms for propagation the health information and educational messages about COVID-19 transmission, prevention, and control. Due to increased awareness of policymakers about the importance of social media platforms, the Egyptian MOHP started recently using COVID-19 sponsored ads on Facebook [15]. Although social media platforms provide an affluent and at hand methods of obtaining information, likewise they can be an origin of misinformation. An eminent example includes fake news on Facebook about potential drugs, and vaccines [21]. Alertness while using these platforms must be regarded, to avoid the circulation of rumors and fabricated data.

As expected, the final years group had a significantly higher score in nearly all knowledge questionnaire (disease transmission, symptoms, and testing) subsections than the early years group. This goes in concordance with a recent Indian COVID-19 awareness survey among health care professionals, where the medical undergraduate students sub-group gave the highest percentage of correct responses (74.10\%) [22]. Final year's group enjoys acceptable knowledge level due to multiple information sources starting from formal curricular teaching, self-directed learning, and informal bedside practice [23]. Moreover, other than formal curriculum teaching, the raised knowledge testified among final year's students may be on account of their previous knowledge regarding the outbreak of MERSCoV which occurred in neighboring Gulf countries in 2015 [24], [25]. Meantime, the fact that more than half of the early year's students believed the possibility of infecting young people are less than the elderly, goes hand in hand with the Egyptian general public COVID-19 survey where great majority of participants believed that the disease complications are more severe in the elderly and people with chronic diseases as diabetes [15]. In China, many studies were published affirming these facts about the disease [26], [27].

Our results uttered that most of early years medical students had a lower level of knowledge about COVID-19 prevention and control subsections. These finding are matching with the disclosures of three analogous survey studies performed at different times in neighboring Saudi Arabia. They all investigated knowledge and information sources among medical students regarding MERS-CoV and ID control [13], [20], [23]. The first one investigated knowledge and attitudes toward (MERS-CoV) and exhibited that the majority of students had significantly lower knowledge compared with the physicians and nurses [13]. The second survey investigated knowledge, attitude, and practice of secondary schools and university students toward (MERS-CoV) epidemic in Saudi Arabia [20]. The third one which investigated medical students' (KAB) regarding standard precautions and infection control, at a Saudi university, were much subsidiary than expected [23]. Causes behind COVID19 poor knowledge resides in the nature of the disease itself, being a newly emerging pandemic disease, information concerning threats of infection and control 
are still explored and investigated rigorously by many scientists in many parts of the world [28], [29].

Saudi Arabia and India had previously reported similar findings among medical students while investigating Zikavirus outbreaks which caused venerable morbidity and mortality in several countries since its epidemic started in Brazil in 2015 [18], [30]. With respect to staying away from crowded places and keep safe distances, almost all our students gave correct answer. This goes in conformity with the Indian COVID-19 awareness survey where the highest number of correct responses regarding correct definition of "close contact" was from the medical undergraduate students [22]. Awareness of the correct "close contact" definition (like the US CDC one) is particularly important for all paramedical personnel such as medical students or managerial staff [31]. Although these groups are not dynamically plunged in patient management, there is high potentiality of having patient contact at certain point in the health-care facilities and accordingly at hazard of contracting and propagation of the infection.

The fact that almost all early years group surpassed in their knowledge regarding the importance of general preventive measures such as covering nose and mouth during coughing (by wearing face masks), reflects the cautious wary among those students more than their older counter fellows. These matches with the Egyptian general public COVID-19 survey where about three quarters of participants believed that putting a face mask can protect from infection [15].

The CDC recently commended putting cloth face masks for the public, especially in regions where there is grave, exalted possibilities of community-based transmission [32]. During the current pandemic time, it is commended that preventive measures guidelines must be set by governments and local public health authorities. Although constant exploitation of masks creates a burden on the limited, available resources, the WHO commends the continuous use of medical masks by $\mathrm{HCW}$ and caregivers in areas of known or suspected community transmission regardless of whether direct care to COVID19 patients is being provided or not [33], [34].

The majority of both early and final year's students correctly believed that home isolation not hospital quarantine must be done for contacts with confirmed cases. This disagrees with the findings of the Egyptian general public COVID-19 survey where nearly sixty percent were willing to stay in the hospital if they contacted an infected case [15].

Another strong predictor of a higher total knowledge score was accomplishment of an ID clinical round which is vital in adapting and retaining ID transmission, prevention, and control knowledge. Many of the early year's students who yielded unsatisfactory replies to questions of the survey lacked clinical experiences due to not yet obtaining their ID clinical rotation [35].
Meantime, the attitude questions where the early year's group significantly outreached the final year's group focused on using personal protective equipment (PPE) such as wearing masks and gloves. In the current study, the most welldistinguished spheres were the general concepts of standard precautions, hand hygiene, and PPE. This is because the medical curricula were rectified to maximize the highlighting of these spheres. Moreover, IPC conveyance is currently early commenced to health sciences students [23], [36], [37]. This goes in concurrence with the Indian COVID-19 awareness survey. For example, the highest number of correct responses regarding awareness of the right sequence for the mask application and hand hygiene was from the undergraduate medical students (42.2\%) [22]. In our study, the majority of medical students significantly believed that there are undeclared numbers in Egypt. A finding of considerable concern which arises from inadequate, under reporting of COVID-19 cases. Due to a combination of insufficient diagnostic kits and tools provided by MOHP and/or the societal stigma associated with COVID-19 infection. Stigma arises due to fear from mortality and the high communicability which results in negative attitudes toward those infected. This can be worked out through meriting education, awareness, and transparency of health-care policies [38]. This goes in accordance with the Egyptian general public COVID-19 survey where $23 \%$ of participants thought the infection of the virus is associated with stigma [15]. Most of students either completely did not believe or did not know whether the government in Egypt could control the spread of the disease. Again, this could be explained by the increased effectiveness of the messages provided by the different social media platforms when used as a source of information. Sometimes, the negative assumptions dominate these platforms for example that media are exaggerating the COVID-19 risk [15]. In addition to, the ambiguity in distinguishing the validity and scientific purport of the official MOHP announcements as well as the likelihood of misinformation being expounded by local health departments [39]. Such departments behave in this way to minimize their responsibility over the disease spread in light of the minimal available resources (inadequately equipped hospitals, few diagnostic tools, and few HCW manpower) to combat COVID19 spread. Again, most of students either completely did not believe or did not know whether this virus is a biological warfare or not. This goes hands in hands with the Egyptian COVID-19 survey among the general public where only quarter of their participants thought that the virus started as a biological weapon. This reflects the raising consciousness of the public when discussing controversial matters [15]. Many sounds lately have suggested that MOHP should temporarily permit senior grades medical undergraduates to treat COVID-19 patients. Such call has been previously made in developing country like India [40]. This initiative 
could help plugging up the insufficiency of HCW and conceivably provide care to larger numbers of people.

\section{Conclusion}

In this study, most of students had unsatisfactory responses of the current pandemic; however, the final year's group had a significantly higher score in nearly all questionnaire $(\mathrm{KAB})$ subsections than the early year's group. The majority of both groups significantly believed that there are undeclared numbers in Egypt. Facebook and other platforms were the most common sources of information. During epidemic time, a safe tool for educational interventions and awareness campaigns about COVID-19, arranged by health-care authorities; is through conducting "periodic webinars" for managing health team which also include medical students.

\section{Limitations}

Our study was "online" limited to the students active on social media who reached the survey, thus the results displayed here may not be generalizable to the rest of the country. Participation bias is also of a concern. Therefore, rounding off further on ground large $\square$ scale studies from other governorates (faculties of medicine and university hospitals) in Egypt is important to further inquire on (KAB) of medical students at the national level.

\section{References}

1. World Health Organization. Corona Virus Disease 2019/ Technical Guidance/Naming the Corona Virus Disease (COVID-19) and the Virus that Causes It. Geneva: World Health Organization; 2019. Available from: https://www.who. int/emergencies/diseases/novel-coronavirus-2019/technicalguidance/naming-the-coronavirus-disease-(covid-2019)-andthe-virus-that-causes-it. [Last accessed on 2020 May 15]. https://doi.org/10.38207/jcmphr20213

2. World Health Organization. Corona Virus Disease (COVID-19) Outbreak Situation. https://www.who.int/redirect-pages/page/ novel-coronavirus-(covid-19)-situation-dashboard. https://doi. org/10.26524/royal.37.10. [Last accessed on 2020 May 15].

3. Center for Systems Science and Engineering (CSSE) at Johns Hopkins University (JHU). Coronavirus COVID-19 Global Cases. Available from: https://www.coronavirus.jhu.edu/map. html. [Last accessed on 2020 May 15]

4. The Central Agency for Public Mobilization and Statistics Website; 2020. Available from: https://www.capmas.gov.eg/ Pages/populationClock.aspx\#. [Last accessed on 2020 Apr 04].

5. Ministry of Health and Population. Available from: https://www.egypt.gov.eg/services/servicesdetails. aspx?ID=63553\&section=serviceproviders $\&$ Cat ID $=1296$. [Last accessed on 2020 May 15].

6. Gupta N, Agrawal S, Ish P, Mishra S, Gaind R, Usha G, et al.
Clinical and epidemiologic profile of the initial COVID-19 patients at a tertiary care centre in India. Monaldi Arch Chest Dis. 2020;90(1):193-6. https://doi.org/10.4081/monaldi.2020.1294 PMid:32290644

7. World Health Organization. Corona Virus Disease 2019/Technical Guidance. Available from: https://www.who.int/emergencies/ diseases/novel-coronavirus-2019/technical-guidance.

8. Ojulong J, Mitonga $\mathrm{KH}$, lipinge $\mathrm{SN}$. Knowledge and attitudes of infection prevention and control among health sciences students at University of Namibia. Afr Health Sci. 2013;13(4):1071-8. https://doi.org/10.4314/ahs.v13i4.30

PMid:24940334

9. Soe HH, Than NN, Lwin H, Phyu KL, Htay MN, Moe S, et al. Knowledge and attitude of mandatory infectious disease notification among final year medical students. J Fam Med Prim Care. 2018;7(4):756-61. https://doi.org/10.4103/jfmpc. jfmpc_300_17 PMid:30234049

10. Patel R, Wattamwar K, Kanduri J, Nahass M. Health care student knowledge and willingness to work in infectious disease outbreaks. Disaster Med Public Health Prep. 2017;11(6):694700. https://doi.org/10.1017/dmp.2017.18 PMid:28625230

11. World Health Organization. Risk Assessment and Management of Exposure of Health Care Workers in the Context of COVID19. Geneva: World Health Organization; 2020. Available from: https://www.apps.who.int/iris/bitstream/handle/10665/331496/ WHO-2019-nCov-HCW_risk_assessment-2020.2-eng.pdf. [Last accessed on 2020 May 15].

12. Sharma K, Jain $P$, Sharma A. Knowledge, attitude and perception of medical and dental undergraduates about antimicrobial stewardship. Indian J Pharmacol. 2015;47(6):676-9. https://doi. org/10.4103/0253-7613.169572

PMid:26729963

13. Asaad AM, El-Sokkary RH, Alzamanan MA, El-Shafei M Knowledge and attitudes towards Middle East respiratory sydrome-coronavirus (MERS-CoV) among health care workers in south-western Saudi Arabia. East Mediterr Health J. 2019;26(4):435-42. https://doi.org/10.26719/emhj.19.079 PMid:32338362

14. Ministry of Health and Population. Preventive Sector. Department of Epidemiology and Surveillance (DES). Available from: http:// www.mohp.gov.eg. [Last accessed on 2020 May 15].

15. Abdelhafiz AS, Mohammed Z, Ibrahim ME, Ziady HH, Alorabi M, Ayyad $\mathrm{M}$, et al. Knowledge, perceptions, and attitude of Egyptians towards the novel coronavirus disease (COVID-19). J Community Health. 2020;45(5):881-90. https://doi.org/10.1007/ s10900-020-00827-7

PMid:32318986

16. Abdelhafiz AS, Fouda MA, El-Jaafary SI, Farghly MI, Salem M, Tammam A, et al. Targeting future customers: An introductory biobanking course for undergraduate students of life sciences. Biopreserv Biobank. 2017;15(4):350-9. https://doi.org/10.1089/ bio.2016.0111

PMid:28574760

17. Facebook Users in Egypt; 2019. Available from: https://www. napoleoncat.com/stats/facebook-users-inegypt/2019/02. [Last accessed on 2020 Apr 04].

18. Ibrahim NK, Moshref RH, Moshref LH, Walid JB, Alsati HS Knowledge and attitudes towards Zika virus among medical students in King Abdulaziz University, Jeddah, Saudi Arabia. J Infect Public Health. 2018;11(1):18-23. https://doi.org/10.1016/j. jiph.2017.02.015

PMid:28697901

19. Kim CJ, Choi WS, Jung Y, Kiem S, Seol HY, Woo HJ, et al. 
Surveillance of the Middle East respiratory syndrome (MERS) coronavirus (CoV) infection in healthcare workers after contact with confirmed MERS patients: Incidence and risk factors of MERS-CoV seropositivity. Clin Microbiol Infect. 2016;22(10):880-6. https://doi.org/10.1016/j.cmi.2016.07.017 PMid:27475739

20. Al-Hazmi A, Gosadi I, Somily A, Alsubaie S, Saeed AB Knowledge, attitude and practice of secondary schools and university students toward Middle East respiratory syndrome epidemic in Saudi Arabia: A cross-sectional study. Saudi J Biol Sci. 2018;25(3):572-7. https://doi.org/10.1016/j. sjbs.2016.01.032

PMid:29686521

21. The Medical Syndicate is Investigating with a Doctor for Prescribing Medications to Treat Covid-19; 2020. Available from: https://www.bit.ly/2x34wlH. [Last accessed on 2020 Apr 04].

22. Modi PD, Nair G, Uppe A, Modi J, Tuppekar B, Gharpure AS, et al. COVID-19 awareness among healthcare students and professionals in Mumbai metropolitan region: A questionnairebased survey. Cureus. 2020;12(4):e7514. https://doi. org/10.7759/cureus.7514

PMid:32377462

23. Khubrani A, Albesher M, Alkahtani A, Alamri F, Alshamrani M, Masuadi $E$. Knowledge and information sources on standard precautions and infection control of health sciences students at King Saud bin Abdulaziz University for Health Sciences, Saudi Arabia, Riyadh. J Infect Public Health. 2018;11(4):546-9. https:// doi.org/10.1016/j.jiph.2017.10.013

PMid:29137958

24. Amin TT, Al Noaim KI, Bu Saad MA, Al Malhm TA, Al Mulhim AA, Al Awas MA. Standard precautions and infection control, medical students' knowledge and behavior at a Saudi university: The need for change. Glob J Health Sci. 2013;5(4):114-25. https:// doi.org/10.5539/gjhs.v5n4p114

PMid:23777728

25. World Health Organization. Infection Prevention and Control during Health Care for Probable or Confirmed Cases of Middle East Respiratory Syndrome Coronavirus (MERS-CoV) Infection: Interim Guidance. Geneva: World Health Organization; 2020. https://doi.org/10.1016/j.jiph.2020.01.181

26. Li LQ, Huang T, Wang YQ, Wang ZP, Liang Y, Huang TB, et al. COVID-19 patients' clinical characteristics, discharge rate, and fatality rate of meta-analysis. J Med Virol. 2020;92(6):577-83. https://doi.org/10.1002/jmv.25924

PMid:32162702

27. Liang W, Guan W, Chen R, Wang W, Li J, Xu K, et al. Cancer patients in SARS-CoV-2 infection: A nationwide analysis in China. Lancet Oncol. 2020;21(3):335-7. https://doi.org/10.1016/ s1470-2045(20)30096-6

PMid:32066541

28. Cascella M, Rajnik M, Cuomo A, Dulebohn SC, Di Napoli R. Features, Evaluation and Treatment Coronavirus (COVID-19). Treasure Island, FL: StatPearls Publishing; 2020.

29. WHO Director-General's Opening Remarks at the Media
Briefing on COVID-19; 2020. https://www.who.int/dg/speeches/ detail/who-directorgeneral-s-opening-remarks-at-the-mediabriefing-on-covid-19---11. [Last accessed on 2020 Mar 19].

30. Gupta N, Randhawa RK, Thakar S, Bansal M, Gupta P, Arora V. Knowledge regarding Zika virus infection among dental practitioners of Tricity area (Chandigarh, Panchkula and Mohali), India. Niger Postgrad Med J. 2016;23(1):33-7. https:// doi.org/10.4103/1117-1936.180179

\section{PMid:27098947}

31. Information for Healthcare Professionals; 2020. Available from: https://www.cdc.gov/coronavirus/2019-ncov/hcp/index.html. [Last accessed on 2020 Mar 19].

32. Recommendation Regarding the Use of Cloth Face Coverings, Especially in Areas of Signifcant Community-Based Transmission; 2020. Available from: https://www.cdc.gov/ coronavirus/2019-ncov/prevent-getting-sick/cloth-face-cover $\mathrm{html}$. [Last accessed on $2020 \mathrm{Apr}$ 04].

33. Coronavirus Disease (COVID-19) Advice for the Public: When and How to use Masks; 2020. Available from: https://www.who. int/emergencies/diseases/novel-coronavirus-2019/advice-forpublic/when-and-how-to-use-masks. [Last accessed on 2020 Apr 04].

34. Feng S, Shen C, Xia N, Song W, Fan M, Cowling BJ Rational use of face masks in the COVID-19 pandemic. Lancet Respir Med. 2020;8(5):434-6. https://doi.org/10.1016/ s2213-2600(20)30134-x

PMid:32203710

35. Justo JA, Gauthier TP, Scheetz MH, Chahine EB, Bookstaver PB, Gallagher JC, et al. Knowledge and attitudes of doctor of pharmacy students regarding the appropriate use of antimicrobials. Clin Infect Dis. 2014:59 Suppl 3(Suppl 3):S1629. https://doi.org/10.1093/cid/ciu537 PMid:25261543

36. Al Kadi A, Salati SA. Hand hygiene practices among medical students. Interdiscip Perspect Infect Dis. 2012;2012:679129. PMid:23024653

37. Petrit BI, Migena G, Indrit B. Knowledge and source of information among health care students on nosocomial infections. Int J Hum Soc Sci Educ. 2014;1(7):46-51.

38. Kabbash IA, Abo Ali EA, Elgendy MM, Abdrabo MM, Salem HM, Gouda MR, et al. HIVIAIDS-related stigma and discrimination among health care workers at Tanta University Hospitals, Egypt. Environ Sci Pollut Res. 2018;25(31):30755-62. https://doi. org/10.1007/s11356-016-7848-x PMid:27752955

39. Hasab A, El-Ghitany EM, Ahmed NN. Situational analysis and epidemic modeling of COVID-19 in Egypt. J High Inst Public Health. 2020;50(1):46-51. https://doi.org/10.21608/ jhiph.2020.87076

40. A Step India is Taking could make Doctor Shortage a NonIssue in Coronavirus Battle; 2020. Available from: https://www. economictimes.indiatimes.com/industry/healthcare/biotech/ healthcare/a-step-indiais-taking-could-make-doctor. [Last accessed on 2020 Mar 29]. 